\title{
The Tenth International Congress of Zoology.
}

IF, as many contrond froflet value of these international ga herings as that they pring into personal touch thefeattered worgerg to single field or the larger number of workero in diferse but allied fields, then the tenth Kongress of Zoologists, held in Budapest on Sept. 3-10 must be pronounced a distinct success. In spite of the clash with the Congress of Geneticists at Berlin, the British Association, and the meeting of Swiss Naturalists, there were registered no fewer than 862 members, though not all actually attended; those who did came from every civilised country north of the equator, and included delegates from 183 universities, academies, museums, and learned societies. The Governments of 24 of those countries were represented by 48 official delegates, those of Great Britain and China being apparently alone in declining the invitation. So far as the British Empire was concerned, the situation was saved by the appointment of Lieut.-Col. R. B. Seymour Sewell, I.M.S., to represent the Government of India. Considering that the Congress was opened in the presence of the Minister of Education, Count Kuno Klebelsberg, and the Ministers or other official representatives of the leading Powers, and considering that on subsequent occasions selected delegates were received and entertained by the Regent and by Count Klebelsberg, it did seem to the British zoologists present that they might have been placed by their Government on a level with their distinguished colleagues from Turkey and Czechoslovakia.

This attitude of the British Government made it seem a shade ironical that the President, Prof. Géza Horváth, should have chosen the English language for just that section of his opening address which set forth the aims and results of applied zoology, the fight against the insect and mammalian enemies of our forestry and agriculture, and the relations of zoology to medicine. Speaking in French, the president sketched the work of the Permanent Committee since the Monaco Congress in 1913, and deplored the death of two of its members, Edmond Perrier and Raphael Blanchard. In German he alluded to the results of experimental genetics and cytology and the help that modern zoology received from chemistry and physics. Finally, in Italian, he dwelt on the difficulty that specialisation placed in the way of a harmonious synthesis, and emphasised the service rendered by such a congress in knitting up the several lines of research.

This specialisation, coupled with the great diversity of the 260 communications presented at the general meetings and to the nine sections, makes it difficult to give a general survey of the scientific proceedings. One may set aside the laborious week spent by the Commission on Nomenclature and the animated but futile discussion in the section on that subject, for the main decisions will shortly be communicated to Nature. One may also, for the immediate purpose, eliminate the section of experimental cytology, which came in rather as an annex to the Congress with the declared and afterwards fulfilled intention of budding off as an independent Congress. The zoology that was left appeared as a very different kind of science from the morphological and systematic zoology of the earlier meetings. The animal and all its parts down to the individual cell are now viewed less in their structural than in their functional aspect. A chord based on this note was struck by the four speakers independently selected by the organising committee to address the opening session.

Prof. R. Hesse, of Berlin, spoke on "The Ecology of Animals : its Aims and Methods," defining ecology as that branch of biology which considers life in relation to its environment. It provides an analysis of the struggle for existence, and its goal is the recognition of the 'Epharmonie,' that is to say, those characters which bring the creature into unison with its environment. A causal explanation would not, said Dr. Hesse, be attained without a more exact knowledge of animal chemistry. Dr. Bather, of the British Museum, speaking as a palæontologist, put to the systematist the question : Quo vadis? In the attempt to adapt a classificatory system, constructed with a different object and on a dissimilar basis, to a representation of phylogeny, systematists had got into a tangle. Greater recognition of similarities due to environment and their expression as classificatory ' grades' might save the situation. The adaptive dynamic characters of an organism were at least as important as the inherited, static characters. Dr. Charles Gravier, of the Paris Museum of Natural History, provided a concrete example of such a study in his account of "La phase pélagique de la vie des annélides polychètes à l'époque de la maturité sexuelle," and described the pairing-dance of the Palolo worm, as observed in the sea by means of a specially constructed lamp. Finally, Prof. R. G. Harrison, of Yale University, spoke on the status and significance of tissue culture. While the isolated cell dies and therefore cannot be observed, a cell-complex cut from the organism could be kept alive for an indefinite period. Carrel, for example, had kept the heart of a chick embryo alive since 1912. The study of living tissue would lead to a knowledge of the finer structure of protoplasm and of its regeneration. Thus the growth of nerve-fibres predicted on theoretical grounds by Ramon y Cajal could be clearly seen in a tissue-culture. The practical importance of tissueculture lay in the help it could give to the fight against cancer.

To follow this theme-the organism as a living entity, working in harmony with its environmentthrough all the variations and illustrations submitted to the sections is impossible here. One can but point to a few of the papers read at the general meetings. In the first of these Prof. H. Spemann, of Freiburg i. B., summarised the novel and important researches of his laboratory on what he terms "organisers" of animal development, a subject on which we hope soon to hear him in London. At the second session Dr. James Ritchie, of the Royal Scottish Museum, lectured on "The Influence of Man on the Development of Faunas." One of the effects on which he laid stress was the gradual killing off of the larger animals, with the result that the fauna of the world was assuming a more uniform character. At the same session Prof. A. Wandel, of Toulouse, directed attention to what he termed "Geographical Parthenogenesis," that is, the existence of species normally with sexual reproduction which in certain regions are strictly parthenogenetic, e.g. North European races of certain crustaceans, flies, butterflies, and other insects.

The third meeting listened to a most interesting lecture by Prof. K. v. Frisch, of Munich, on the senses and 'speech' of bees; to some new observations by Dr. G. Brandes, of the Dresden Zoological Garden, on the life of the orang-utan; to an account by $\mathrm{L}$. R. Natvig, of Oslo, of the breeding of Reindeer in Norway, where they number 135,000, and of the methods of fighting their parasites; to the description by Prof. P. Buchner, of Greifswald, of the symbiosis obtaining between certain wood-eating insects and fungi and infusoria; and to an account of some new experiments by Prof. Gilbert Rahm, of Fribourg,

No. 3025, VoL. 120] 
which showed that life-processes could be entirely suspended in certain organisms without danger to life. At the fourth session a large audience gathered to hear Prof. Voronoff, of Paris, and his pupil, Dr. Nemes Nagy, of Budapest, but had first to listen to Prof. Novikoff, of Prag, on the value of a study of analogy, and to Dr. J. Ertl, of Budapest, on the practical results obtained with human subjects by the regeneration and transplantation of tissue, the most remarkable being those cases in which bone was transplanted. But the most applauded lecture of the Congress was that by Dr. Canti, of St. Burtholomew's, which had to be given three times. Dr. Canti's highly instructive films showing the growth of tissue and the actual division and mitosis of cells, have been shown more than once in London, but on this occasion he added films in which the results of irradiation by radium on the living tissue were clearly demonstrated. Dr. Canti had the honour of showing his film to Count Stefan Bethlen and Count Géza Teleki.

During the Congress mernbers had the opportunity of visiting various museums and institutes, such as the National Museum, the Ornithological and Geologieal Institutes, the Zoological Garden, and the magnificent museum for agriculture, forestry, and land development, admirably adapted to the Hungary of pre-War days with its mines, its quarries, and its forests, but a melancholy reminder to the Hungary of to-day. The present wealth of Hungary lies in the herds and flocks of the great plain, which members had an opportunity of seeing on an excursion to the Hortsbagy Puszta, and in the vigour of its people all inspired with an intense desire to maintain the highest lovel of civilisation, as exemplified in the clinies of Debrecen University and the Biological Institute on Lake Balaton.

Small space is left in which to record the kindness and hospitality shown to foreign members by the Government, the Municipality of Budapest, the directors of the various institutes, and indeed all with whom the visitors were brought into contact. It pleased all to hear at the concluding meeting that the president, Prof. Horvath, had just received the Hungarian Cross for Distinguished Service of the Second Class.

The next rneeting of the Congress is to be in Padua in 1930, under the presidency of Prof. Paolo Enriques. Prof. L. Joubin (Paris) has been elected president of the Permanent Committee, with Dr. M. Caullery as Secretary.

\section{University andrEducational Intelligence.}

BIRMINGFAy A legacy of $£ 2000$, bequeathed by the late M Afristopke Gllins, is to be added to the Biolgg cy isuildizg ton

Noby tis retire nent front the chair of physiology, Prof. E. Carlie has presented 120 volumes to the library of the Physidery Department. Prof. Carlier has also given to the department a most valuable set of 3000 microscopic preparations from his private collection, together with a number of teaching diagrams.

The Huxley Lecture is to be delivered on Thursday, Dec. 1, by Prof. A. S. Eddington, Plumian professor of astronomy and experimental philosophy in the University of Cambridge.

Among changes of the lecturing staff are the following : Resignations-Mr. H. P. Dean (mechanical engineering), Mr. L. Eastham (zoology), Mr. J. P. Rees (mining), Mr. O. C. Elvins (oil engineering). Appointments : Mr. D. A. M. Sandifer (mechanical engineering), Mr. D. I. Gumn (zoology), Dr. W. Hancock (mine rescue work), Mr. R. Glossop (metal mining).
Cambridas. For the seventh year in succession, Trinity College announces the offer of a Research Studentship open to graduates of other universities who propose to go to Cambridge in October next as candidates for the degree of Ph.D. The value of the Studentship may be as much as $\mathfrak{E 3 0 0}$ a year if the pecuntary circumstances of the successful candidate reguire so large a sum. Applications must reach the Senior 'Tutor not later than July 1, 1928.-- The same College offers, as usual, Dominion and Colonial Exhibitions to students of Dominion and Colonial Universities who wish to go to Cambridge next October as candidates for the degree of B.A., M.Litt., M.Sc., or Ph.D. The Exhibitions are of the titular value of $£ 40$, but their actual value is such sum (if any) not exceeding the titular value as the College Council may from time to time hold to be justified by the Exhibitioner's financial circumstances. If it is made clear that the financial need of an Exhibitioner cannot possibly be met by the payment to him of the full amount of his titular ernolument the Council has power, if it sees fit and if funds are available, to award him an additional payment. Candidates must apply through the principal authority of their university, and applications should reach the Senior Tutor (from whom further particulars may be obtained) by July 1, 1928 .

Evinburah. Drst. H. O'Donoghue, professor of zoology the fhiversity of Manitoba, Winnipeg, has been apdofued to a senjor lectureship in zoology, and Miss Trene A. F. Thitop, to a junior lectureship in zoology.

Manchester.-Dr. R. B,Wild, who has recently retired from the Leegh chplr of materia medica and therapeutios, has add a gift of $\mathrm{E250}$ for the endowment of a plitongharmacology.

The folld irf appointurents have been made: Assistant lectufer if Assistant lecturer in keorogy, Dr. M. B. Hodge; assistant lecturer in baderiology, Mr. C. A. MeGaughey; demonstrator in bacteriolgy, Mr. E. St. G. Gilmore; demonstrator in pathology, Mr. H. L. Sheehan; demonstrator in chemical technology, Mr. C. Chew.

SHEFFLCLD.-The University Council has made the following appointments : R. Cooper, assistant lecturer in mathematics ; Dr. F. C. Chalklin, assistant lecturer in physics; and Miss Flora M. V. Brown, part-time assistant lecturer in botany.

Trre Committee of the Leplay House Educational Tourg Association has arranged a visit to Sicily during the coming Christmas vacation to study the history of the Island, mainly through its architecture, under the leadership of Mr. Stanley Ramsey. A regional survey meeting will be held at the Collège des Ecossais, Montpellier, at the invitation of Prof. P. Geddes; the studies will be under the direction of Mr. Ceorge Morris. Full particulars can be obtained from Miss Margaret Tatton, Leplay House, 65 Belgrave Road, Westminster, S.W.I.

MR.AH. G. BEARD, research assistant in the Depart. ment of Colour Chemistry at the Technical College, Hyddersfield, has been appointed research chemist af Woolwich Arsenal. Mr. Beard has received the whole of his chemical education at the Huddersfield Technical College, and for the past four years has been working under the supervision of Dr. H. H. Hodgson, head of the Department, with whom he has been the joint author of numerous papers published by the Chemical Society and the Society of Chemical Industry. 